\title{
Temperature-independent Detection of Heteroduplex and Homoduplex Fragments Applying Poly(glycidylmethacryate-co-divinylbenzene-based) Monoliths Modified to Strong Anion-exchanger
}

\author{
Said H. Lubbad \\ Department of Chemistry, Al-Azhar University-Gaza, Gaza, Palestine \\ *Corresponding author: E-mail: s.lubbad@alazhar.edu.ps, slubbad66@yahoo.com \\ Tel: +972 (0) 8- 2641884 Fax: +972(0) 8- 2641888
}

Received: 28-11-2014

\begin{abstract}
Monoliths of poly(glycidylmethacrylate-co-divinylbenzene) were prepared in the confines of presilanized borosilicate glass columns $(100 \times 3 \mathrm{~mm}$ I.D.). These monoliths were surface modified into strong anion-exchangers with hydrochloric acid (10\%) and triethylamine, successively. The strong anion-exchanger established good separation of 5-phosphorylated oligodeoxythymidylic acids fragments $\left[\mathrm{d}(\mathrm{pT})_{12-18}\right]$. Moreover, heteroduplex and homoduplex fragments of a low-range mutation standard [of STS marker from the Y-chromosome (209 bp)] were separated at ambient and elevated temperatures using sodium phosphate buffer and a gradient former of sodium chloride, in anion-exchange high-performance liquid chromatography (AE-HPLC). This is a step forward for mutation detection as temperature-independent method, which is not the case in denatured ion-paired reversed-phase chromatography (D-IP-RP-HPLC), where mutation detection is temperature critical and might be bypassed if temperature changes slightly. Finally, reproducibility check from run-to-run and monolith-to-monolith showed a relative standard deviation (RSD) of less than $2 \%$.
\end{abstract}

Keywords: Strong anion-exchanger (SAX); Monolith, Glycidylmethacrylate-co-divinylbenzene; Homoduplex and heteroduplex fragments.

\section{Introduction}

High-performance liquid chromatography (HPLC) has been the most liable technique for separation of proteins and nucleic acids. ${ }^{1-4}$ However, the high back-pressure and the long analysis time experienced have presented a setback for packed columns. Fast separation is feasible using monolithic stationary phases consisting of a single piece of a rigid macroporous polymer. Monoliths are distinguished for fast analysis due to the ample channels available, which allow high flow-rate at low pressure-drop, as well as high mass transfer due to enhancing convection and lessening diffusion. ${ }^{5,6}$ Monoliths have been prepared from different materials such as inorganic silica by sol-gel ${ }^{7-9}$ or organic polymer such as metal-catalyzed ring opening metathesis polymerization (ROMP) ${ }^{10}$ or free-radical polymerization based on styrene and acrylate chemistry. ${ }^{11-13}$ The ease to make and derivatize, made these monoliths a good choice for present and future applications in bioseparation.
Ion-pair reversed-phase (IP-RP-HPLC) and anionexchange (AE-HPLC) high-performance liquid chromatography are the most practical methods for nucleic acids separation. ${ }^{14-19}$ Anion-exchange chromatography mode presents an efficient and environmentally benign method for proteins and nucleic acid analyses either for diagnostic or disease treatment purposes. ${ }^{20-21}$ Moreover, AE-HPLC has been applied for mutation detection in $d s$ DNA fragments that is of great importance in medicine, natural and social sciences. Such a separation of heteroduplex and homoduplex fragments of different mass ranges at different temperatures is accomplished. ${ }^{16,22}$ The separation of hetero- and homo-duplex fragments using AEHPLC monolithic column is advantageous to D-IP-RPHPLC, where the latter is temperature critical. Minor discrepancy in the column temperature would lead to miss spotting of the mutation presence in the sample. This is not the case in AE-HPLC, where mutation is detected at a wide range of temperature. The $d s$ DNA fragments (with 
negative potential of the phosphate groups) are attracted to the positive potential of the anion-exchanger (ammonium groups). ${ }^{2,16}$

Mutation presence is usually detected by the presence of four peaks in the chromatogram, two for homoduplex and two for the heteroduplex fragments, where the elution order depends on the method applied for its detection. $^{14,16}$

Few previous studies employed glycidylmethacrylate-co-divinylbnezene-based monoliths which were surface modified into weak and strong anion exchangers, taking advantage of the reactivity of the epoxy groups on the support surface. ${ }^{23-27}$. The benzene ring in DVB furnishes hydrophobic interaction between the supports and analytes. Poly (glycidylmethacrylate-co-divinylbenzene)based monoliths are unique in two aspects; one is due to better hydrophobic interaction with analyte than in poly(GMA/EDMA)-based monoliths, and another it is easier to surface functionalize than poly(PS/DVB)-based monoliths. Moreover, poly(GMA-DVB)-based supports are more tolerant to changing the solvent $\mathrm{pH}$ than poly(GMA/EDMA), and consequently more stable supports.

In this study, a monolith, made of divinylbenzene and glycidylmethacrylate modified into strong anion-exchanger, was investigated for the analysis of low-range mutation standard [STS marker from the Y-chromosome (209 bp)].

\section{Experimental}

\section{1. Chemicals and Reagents}

All HPLC-analyses were performed using HPLCgrade water and acetonitrile (ACN). Triethylamine was used with no further purification (Sigma, Germany); divinylbenzene and glycidylmethacrylate purchased from Sigma (Germany) were extracted with $10 \%$ sodium bicarbonate solution, dried then distilled under vacuum. 2,2diphenyl-1-picryl-hydrazyl hydrate (DPPH), $\alpha, \alpha^{\prime}$ azoisobutyronitrile (AIBN) and 3-(trimethoxysilyl)propyl methacrylate were used as purchased from Sigma (Germany). 1-Decanol was vacuum distilled and tetrahydrofuran (THF) was dried over sodium and distilled before use (Sigma, Germany). Polystyrene standards for ISEC analysis were purchased from Pressure Chemicals (Pittsburgh, PA, USA) (Mr.: 800; 1681; 4000; 13502; 65000; 129200; 670000, $2000000 \mathrm{~g} / \mathrm{mole})$ and from Polymer Standards Service (Mainz, Germany) (Mr.: 370; 271000; 1103000; 3000000; $4060000 \mathrm{~g} / \mathrm{mole})$. Sodium dihydrogen phosphate $\left(\mathrm{NaH}_{2} \mathrm{PO}_{4}\right)$, sodium hydroxide, sodium nitrate, acetic acid, and phosphoric acid were purchased from Sigma (Germany) and used in buffer preparations. A buffer of sodium dihydrogen phosphate $(0.02 \mathrm{M})$, $20 \%(v / v)$ acetonitrile was prepared by adjusting the solution $\mathrm{pH}$ with sodium hydroxide or phosphoric acid to the required $\mathrm{pH}$. 5-phosphorylated oligodeoxythymidylic acids fragments $\left[\mathrm{d}(\mathrm{pT})_{12-18}\right]$ sample was purchased from Sigma (Vienna, Austria). Low-range mutation standard [STS marker from the Y- chromosome (209 bp)] was purchased from Transgenomics (Berlin, Germany).

\section{2. Instrumentation}

HPLC-system of Transgenomic (Transgenomics, Berlin, Germany) was used in the analyses. The Transgenomic HPLC-system consisted of a pump, oven, autosampler, and UV-Vis detector. Nucleic acids were detected by UV-Vis detector at wavelengths of $260 \mathrm{~nm}$. Wavemaker 4.0 (Transgenomics, Berlin, Germany) was used for data acquisition and processing. Nanopure infinity ultra-pure water and HPLC-grade acetonitrile were used in HPLC analyses. Borosilicate glass columns [Chromsep glass column $(100 \times 3 \mathrm{~mm}$ I.D. $)$, catalogue number CP99912] were purchased from CP-Analytica (Vienna, Austria).

\section{3. Silanization of Borosilicate Glass Columns}

The borosilicate glass columns $(100 \times 3 \mathrm{~mm}$ I.D. $)$ were silanized by sonicating them in a mixture of ethanol/acetone $(1 / 1, v / v)$, and then etched by soaking them in $2 \mathrm{~mol} / \mathrm{L} \mathrm{KOH} / \mathrm{ethanol}$ solution overnight at a temperature of $60^{\circ} \mathrm{C}$. The following day, these columns were washed with plenty amount of water while sonication till reaching neutral effluents and dried under high vacuum for $6 \mathrm{~h}$. A mixture, of 3-(trimethoxysilyl)propyl methacrylate (silanizing agent) and equal volume of $0.01 \%(\mathrm{w} / \mathrm{v})$ 2,2-diphenyl-1-picrylhydrazyl hydrate in dimethylformamide (DPPH/DMF) (as inhibitor to avoid temperature induced-polymerization of the silanizing agent), was filled into the glass columns, which were sealed using Eppendorf 2-ml vials and kept to react at temperature of $100{ }^{\circ} \mathrm{C}$ for $6 \mathrm{~h}$. These columns were sonicated in acetone, water then ethanol for $15 \mathrm{~min}$ each, dried under high vacuum for $6 \mathrm{~h}$ and stored under argon for further use.

\section{4. Monolith Preparation}

Mixtures of specific combinations of glycidylmethacrylate, divinylbenzene, 1-decanol and THF (as macroporogen and microporogen, respectively) were prepared. $1 \%(w / v)$ of $\alpha, \alpha^{\prime}$-azoisobutyronitrile (AIBN) was used to initiate polymerization. Each mixture was degassed and sonicated for $10 \mathrm{~min}$, then poured inside the presilanized borosilicate glass column $(100 \times 3 \mathrm{~mm}$ I.D. $)$. Then it was sealed on both sides by Eppendorf 2-ml vials. The column was left to polymerize for $24 \mathrm{~h}$ at $55^{\circ} \mathrm{C}$. Afterward, the seals were removed and the monolith was cut flat at both sides, fitting rings were placed and the monolith was placed in special stainless steel housing 
(Chromsep column holder $10 \mathrm{~cm}$, catalogue number CP23082) purchased from CP-Analytica (Vienna, Austria). Each monolith made was flushed with acetonitrile for $1 \mathrm{~h}$ at flow-rate of $0.1 \mathrm{~mL} / \mathrm{min}$, to flush out the porogens and non-reacted monomers. Afterwards, each monolith was treated accordingly.

\section{Results and Discussion}

\section{1. Optimization of Monolithic Support}

Monoliths of various recipes were prepared by changing the co-monomer contents maintaining $1 \%(\mathrm{w} / \mathrm{v})$ AIBN at temperature of $55^{\circ} \mathrm{C}$. As a starting point, a monolith was prepared of GMA, DVB, 1-decanol, and THF as $20,20,52$, and $8 \%(v / v)$, respectively. This monolith was highly dense showing high back pressure at low flow-rate, which represented a serious problem for further derivatization. A second monolith of 15, 15, 60, 10\% ( $/ / \mathrm{v})$ as GMA, DVB, 1-decanol, and THF, respectively, was prepared. This monolith was not rigid enough and experienced compression. A third monolith was made of 17.5, 17.5, 56, and 9\% $(v / v)$ as GMA, DVB, 1-decanol, and THF, respectively. This monolith was mechanically stable and established a good flow-through at relatively low back-pressure. Fig. 1 is a plot of the pressure-drop vs. flow-rate for this monolith before and after derivatization, where a linear regression of 0.9996 was determined over a range of $1.0-4.0 \mathrm{ml} / \mathrm{min}$ using $15 \%(v / v)$ acetonitrile/water.

\section{2. Permeability and Porosity}

The hydrodynamic stability of monolithic columns is very important for their application in chromatographic systems. A relatively low pressure-drop through the column is favored to achieve a suitable flow-rate for separation; i.e. higher permeability is always an advantage for monoliths. The permeability for monolith presented in this paper was calculated, and found to be $1.38 \times 10^{-13} \mathrm{~m}^{2}$ and $1.19 \times 10^{-13} \mathrm{~m}^{2}$, for the monolith before and after surface modification to ion-exchanger, respectively. These values indicate the high flow-permeability of the monolith with marginal decrease in permeability after monolith surface modification.

Finally, the monolith was subjected to inverse size exclusion chromatography (ISEC), which enables determining the total porosity and pore size distribution. ISEC is a very reliable method to check support porosity, as analysis is performed in wet columns mimicking the situation in chromatographic separation. ISEC experiments were performed using toluene and polystyrene (PS) standards in the molecular weight range of 370-4060000 $\mathrm{g} / \mathrm{mol}$.

The total volume fraction occupied by the mobile phase $\left(\boldsymbol{\varepsilon}_{\mathbf{t}}\right)$, the volume fraction of the intermicroglobule void volume $\left(\varepsilon_{\mathbf{z}}\right)$, and The volume fraction of pores within the globules $\left(\boldsymbol{\varepsilon}_{\mathrm{p}}\right)$ were found to be $0.75,0.59,0.16$ (for monolith before surface modification) and $0.74,0.54$, 0.20 (for monolith after surface modification), respectively.

The higher pressure-drop and lower permeability, of the monolith after surface modification, is indicated by the lower value of $\varepsilon_{\mathrm{z}}$, the pores accessible to the mobile phase, which decreased from 0.59 to 0.54 . $\varepsilon_{\mathrm{t}}$ is almost the same for the monolith before and after surface modification, since only surface modification is performed. A good consistency between permeability and porosity check is established.

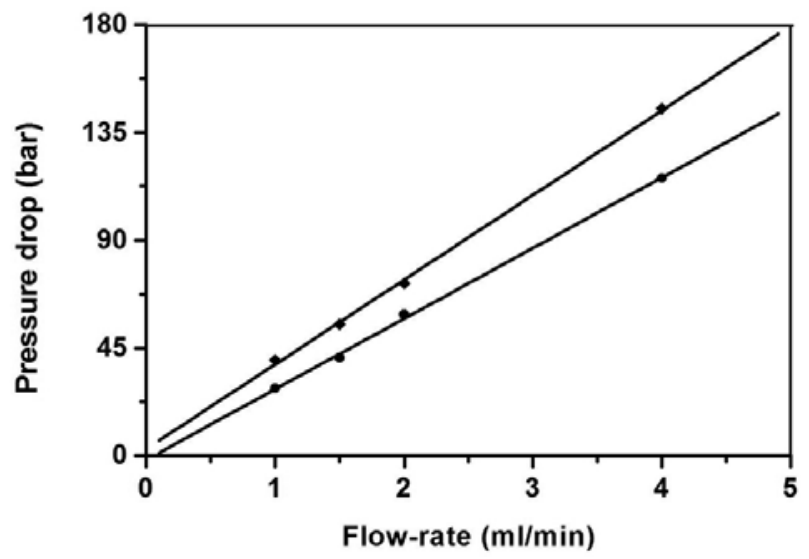

Fig. 1. A plot of pressure-drop versus flow-rate on 35\% ( $v / v)$ DVBGMA-based monolith applying a solvent of $15 \%$ acetonitrile/water $(\bullet)$ before derivatization $(\bullet)$ after derivatization.

\section{3. Strong Anion-exchange Derivatization \& Ion-exchange Capacity Quantification}

A strong anion-exchanger was prepared applying a new approach to surface modify a glycidylmethacrylatebased monolith (Scheme 1). The monolith was treated with hydrochloric acid (10\%) at low flow-rate of 0.05 $\mathrm{mL} / \mathrm{min}$ using a syringe pump, then sealed and stored overnight at room temperature. The following day, the monolith was flushed with plenty amount of water till reaching neutral effluent followed by $10 \mathrm{~mL}$ of THF. Afterwards, $15 \mathrm{~mL}$ of triethylamine was introduced into the monolith at temperature of $80{ }^{\circ} \mathrm{C}$ over $2 \mathrm{~h}$. Then the monolith was sealed and kept at temperature of $80{ }^{\circ} \mathrm{C}$ overnight. The monolith was then flushed consecutively with $30 \mathrm{~mL}$ of acetonitrile, $10 \mathrm{~mL}$ of methanol, and 100 $\mathrm{mL}$ of water. Each monolith was conditioned with sodium phosphate buffer $(0.02 \mathrm{M}, \mathrm{pH} 7)$ for $2 \mathrm{~h}$ before analysis. By the end of analyses, the ion-exchange capacity of the functionalized monolith was determined by frontal and elemental analysis. The frontal analysis was carried out using breakthrough experiments in which a $0.25 \mathrm{M}$ solution of sodium nitrate and applying flow-rates of 0.5 and 1.0 


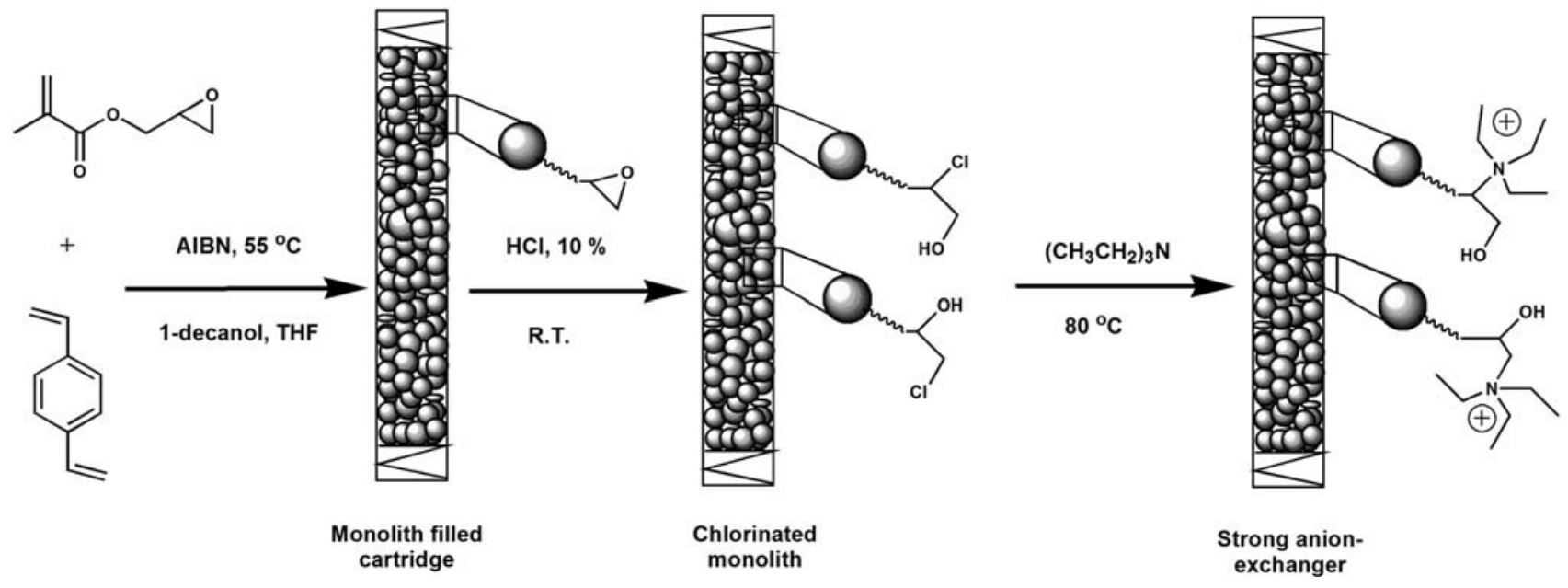

Scheme 1. Preparation of strong-anion exchange monolith based on glycidylmethacrylate-co-divinylbenzene.

$\mathrm{mL} / \mathrm{min} .{ }^{28}$ The ion-capacity quantified by frontal analysis was $0.81 \mathrm{meq} / \mathrm{g}$ and by elemental analysis was 0.87 $\mathrm{meq} / \mathrm{g}$. These values are consistent showing a deviation of less than $10 \%$.

\section{4. Separation of 5-phosphorylated Oligodeoxythymidylic Acids Fragments [d(pT) $)_{12-18}$ ]}

The strong anion-exchange monolith synthesized was analyzed for separation of 5-phosphorylated oligodeoxythymidylic acids fragments $\left[\mathrm{d}(\mathrm{pT})_{12-18}\right]$ to check its performance. The usual operating mobile phase pH's applying strong anion-exchange columns is $7-9 .{ }^{2,17,29}$ As a starting point a phosphate buffer $(0.02 \mathrm{M}$, $\mathrm{pH} \mathrm{7,20 \%} \mathrm{ACN)} \mathrm{and} \mathrm{NaCl}$ as a gradient former were used. Good separation of the seven fragments of oligodeoxythymidylic acids was accomplished in about 12 min (Fig. 2). Applying a gradient of sodium chloride [as eluting salt (23-30)\% in $4 \mathrm{~min}$, then to $35 \%$ in $10 \mathrm{~min}$ at a flow-rate of $2 \mathrm{ml} / \mathrm{min}$ ], the resolution of the seven fragments ranged from 1.2 to 1.46 (Table 1 ). To check the $\mathrm{pH}$ influence on separation of $\mathrm{d}(\mathrm{pT})_{12-18}$, phosphate buffers $(0.02 \mathrm{M}, 20 \% \mathrm{ACN}$, pHs 8.0 and 9.0$)$ were used. When increasing the buffer $\mathrm{pH}$ from 7 to 8 , applying the same conditions as mentioned above, the analysis time of $\mathrm{d}(\mathrm{pT})_{12-18}$ sample was decreased by 2 min and resolution was reduced by only $\sim 10 \%$ in average (Fig. 2, \& Table 1). When switching to buffer of $\mathrm{pH} \mathrm{9,} \mathrm{no} \mathrm{significant} \mathrm{influ-}$ ence was seen where the analysis time and the resolution were almost the same (Fig. 2, Table 1). This is in consistence with what was reported in a relatively recent study ${ }^{19}$ which stated that the higher the $\mathrm{pH}$ of the eluting buffer, the faster the elution is for $\mathrm{d}(\mathrm{pT})_{12-18}$ fragments. However, this contradicts what was reported by a previous study, ${ }^{23}$ which concluded a delayed elution of $\mathrm{d}(\mathrm{pT})_{12-18}$ fragments when increasing the $\mathrm{pH}$ of the eluting buffer.

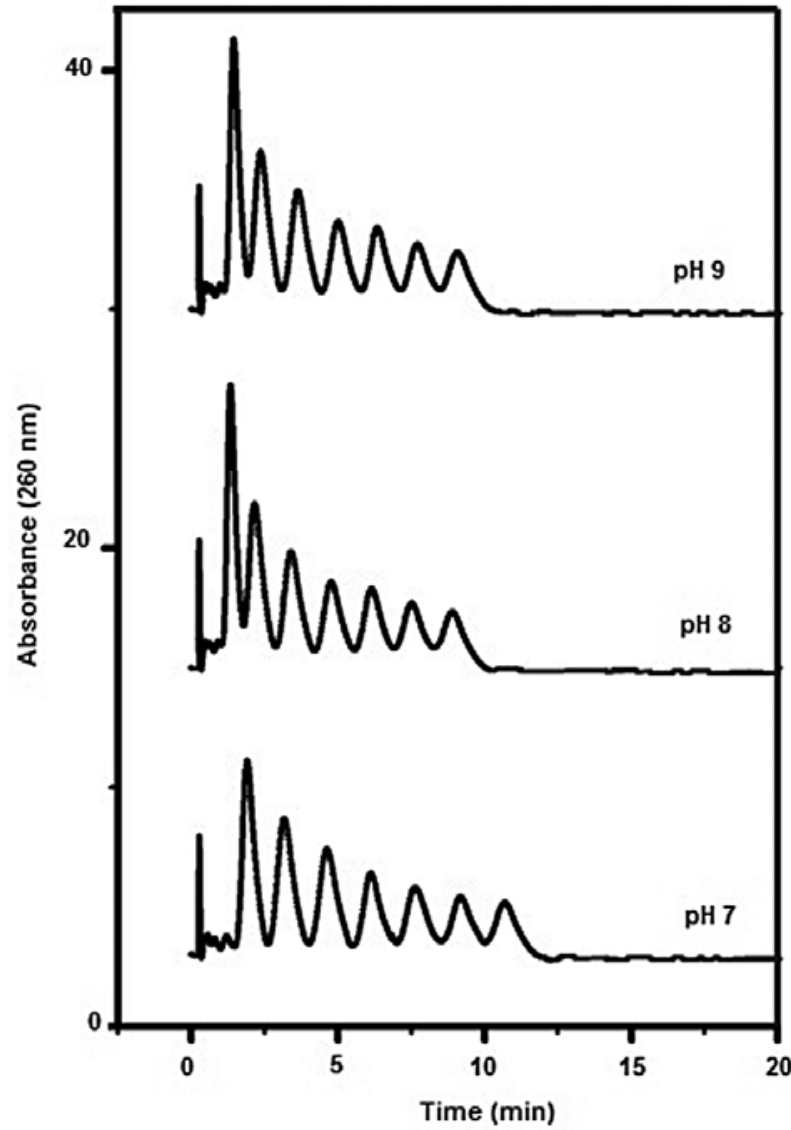

Fig. 2. Influence of solvent $\mathrm{pH}$, of 7, 8, and 9, on the separation of 5-phosphorylated oligodeoxythymidylic acids fragments [d(pT) $)_{12-18}$, on strong anion-exchange DVB-GMA-based monolith. Mobile phase, A: $0.02 \mathrm{M}$ sodium phosphate buffer, $20 \%$ acetonitrile; B: 0.02 M sodium phosphate buffer, $20 \%$ acetonitrile, $1.0 \mathrm{M}$ sodium chloride; gradient, $23 \% \mathrm{~B}$ for $1 \mathrm{~min}, 23-30 \% \mathrm{~B}$ in $4 \mathrm{~min}, 30-35 \% \mathrm{~B}$ in $15 \mathrm{~min}$; flow-rate, $2 \mathrm{~mL} / \mathrm{min}$; temperature, $25^{\circ} \mathrm{C}$; sample, $5 \mu \mathrm{g} \mathrm{d}(\mathrm{pT})_{12-18}$.

This higher retention was rationalized on the base of an increasing deprotonation of the phosphate terminals of the oligonucleotides fragments at higher $\mathrm{pH}$ values, which 
increases their affinity to the positive surface of the chromatographic bed. ${ }^{23}$ However, the authors totally disregarded the increased interaction of hydroxide ions with the anion-exchanger sites in competition with the analytes, as the solvent $\mathrm{pH}$ increases. ${ }^{19}$ Moreover, increasing the hydroxide ion concentration increases the solvent ionic strength and leads to faster elution of the oligonucleotide fragments, ${ }^{19}$ as observed in this study.

\section{5. Separation of Heteroduplex and Homoduplex Fragments}

\section{5. 1. Mutation \& Mutation Samples}

The low-range mutation sample (209bp) investigated in this study was a point mutation as AC, GT mismatch. The sample sequence is sated below, where the first underlined bold is the normal base and the second underlined bold is the variant base,

Low range mutation standard [STS marker from the Y-chromosome (209 bp)]

AGGCACTGGTCAGAATGAAGTGAATGGCACACA GGACAAGTCCAGACCCAGGAAGGTCCAGTAACAT GGGAGAAGAACGGAAGGAGTTCTAAAATTCAGG GCTCCCTTGGGCTCCCCTGTTTAAAAATGTAGG TTTTATTATTATATTTCATTGTTAACAAAAGTCC A/GTGAGATCTGTGGAGGATAAAGGGGGAGCTGT ATTTTCCATT

The entirely complementary base sequence of both strands are called a homoduplex; while a duplex that contains at least one base pair, which is not complementary (mismatch), is called a heteroduplex.. ${ }^{16,30}$ The most common mismatches in heteroduplex are $\mathbf{A C}$ and $\mathbf{G T},{ }^{31}$ which is the case in the STS marker from the Y-chromosome.

\section{5. 2. Analysis of Mutation Applying Anion-exchanger Monolith}

In this study, a mutation sample was analyzed at room and elevated temperatures, on anion-exchange sup- port to compare the chemically and thermally induced denaturation of the double-stranded $d s$ DNA. The chemicalinduced denaturation is due to interaction between the $d s$ DNA and the buffer solution. Low-range mutation sample was analyzed at ambient temperature applying phosphate buffer (0.02 M, pH 8), and sodium chloride (1.0 M) as gradient former. The four peaks of homoduplex and heteroduplex fragments were detected (Fig. 3a). The peaks of homoduplex were clearly resolved from those of heteroduplex.

To check the temperature influence on separation of heteroduplices from homoduplices, temperature was elevated from 25 to 40,55 , and $70{ }^{\circ} \mathrm{C}$ (Fig. 3b-d) maintaining identical chromatographic conditions. Increasing the column temperature to 40 and $55^{\circ} \mathrm{C}$ lead to better separation of AT from GC (of the homoduplex fragments), and AC from GT (of the heteroduplex fragments), (Fig. 3b,c). At column temperature of $70{ }^{\circ} \mathrm{C}$, it was noticed that the homoduplex AT and the heteroduplex GT started to coelute (Fig. 3d). Nevertheless, the four peaks were always seen at the four temperatures studied, which is tentative for mutation presence. Furthermore, applying 5\% acetonitrile as organic modifier (Fig. 3e), maintaining similar chromatographic conditions applied in Fig. 3b, improved the resolution of the four peaks of AT, GC, AC and GT. Finally, decreasing the flow-rate from 1.0 to $0.5 \mathrm{~mL} / \mathrm{min}$ at temperature of $25^{\circ} \mathrm{C}$ demonstrated good separation of the four fragments AT, GC, AC, and GT (Fig. 3f) but doubled the analysis time. To sum up, the four peaks were seen clearly at all conditions applied, which assure no bypass of the mutation detection, applying this proposed method. The change in analysis temperature caused minor improvement in separating the homo- and heteroduplex peaks, which is a result of two effects: First, it enhances denaturation of the $d s$ DNA ladder, this results in different affinities of the chromosomes toward the stationary phase and consequently better resolution. Second, the higher temperatures cause the $d s$ DNA ladder to flatten (uncurl) and consequently lead to higher interaction with the support, and again better resolution. ${ }^{1-2,18}$

Table 1. Comparison of retention time $\left(\mathrm{t}_{\mathrm{R}}\right)$, peak half width $\left(\mathrm{W}_{0.5}\right)$ and resolution $\left(\mathrm{R}_{\mathrm{s}}\right)$ of $\mathrm{d}(\mathrm{pT})_{12-18}$ fragments on strong anion-exchange DVB-GMDbased monolith $(100 \times 3 \mathrm{~mm} \mathrm{I.D}$.). Mobile phase, A: $0.02 \mathrm{~mol} / \mathrm{l}$ sodium phosphate ( $\mathrm{pHs} 7,8, \&$ 9, $20 \%$ acetonitrile); B: mobile phase A + $1.0 \mathrm{~mol} / \mathrm{L}$ sodium chloride; gradient, $23-30 \% \mathrm{~B}$ in $4 \mathrm{~min}$, then to $35 \%$ in $10 \mathrm{~min}$; flow-rate, $2 \mathrm{~mL} / \mathrm{min}$; temperature, $25^{\circ} \mathrm{C}$; sample, $5.0 \mu \mathrm{g} \mathrm{d}(\mathrm{pT})_{12-18}$.

\begin{tabular}{lccccccccc}
\hline Fragment & & $\mathbf{p H ~ 7}$ & & & $\mathbf{p H ~ 8}$ & & & $\mathbf{p H ~ 9}$ & \\
& $\mathbf{t}_{\mathbf{R}}$ & $\mathbf{W}_{\mathbf{0 . 5}}$ & $\mathbf{R}_{\mathbf{s}}$ & $\mathbf{t}_{\mathbf{R}}$ & $\mathbf{W}_{\mathbf{0 . 5}}$ & $\mathbf{R}_{\mathbf{s}}$ & $\mathbf{t}_{\mathbf{R}}$ & $\mathbf{W}_{\mathbf{0 . 5}}$ & $\mathbf{R}_{\mathbf{s}}$ \\
\hline $\mathrm{d}(\mathrm{pT})_{12}$ & 1.91 & 0.50 & 1.46 & 1.34 & 0.37 & 1.05 & 1.45 & 0.41 & 1.17 \\
$\mathrm{~d}(\mathrm{pT})_{13}$ & 3.16 & 0.51 & 1.35 & 2.16 & 0.56 & 1.21 & 2.36 & 0.51 & 1.18 \\
$\mathrm{~d}(\mathrm{pT})_{14}$ & 4.62 & 0.77 & 1.20 & 3.40 & 0.66 & 1.21 & 3.63 & 0.76 & 1.18 \\
$\mathrm{~d}(\mathrm{pT})_{15}$ & 6.13 & 0.73 & 1.20 & 4.77 & 0.68 & 1.19 & 5.02 & 0.64 & 1.05 \\
$\mathrm{~d}(\mathrm{pT})_{16}$ & 7.64 & 0.77 & 1.21 & 6.15 & 0.69 & 1.19 & 6.21 & 0.70 & 1.31 \\
$\mathrm{~d}(\mathrm{pT})_{17}$ & 9.18 & 0.74 & 1.15 & 7.51 & 0.67 & 1.09 & 7.71 & 0.66 & 1.09 \\
$\mathrm{~d}(\mathrm{pT})_{18}$ & 10.68 & 0.80 & - & 8.89 & 0.83 & - & 9.02 & 0.77 & - \\
\hline
\end{tabular}



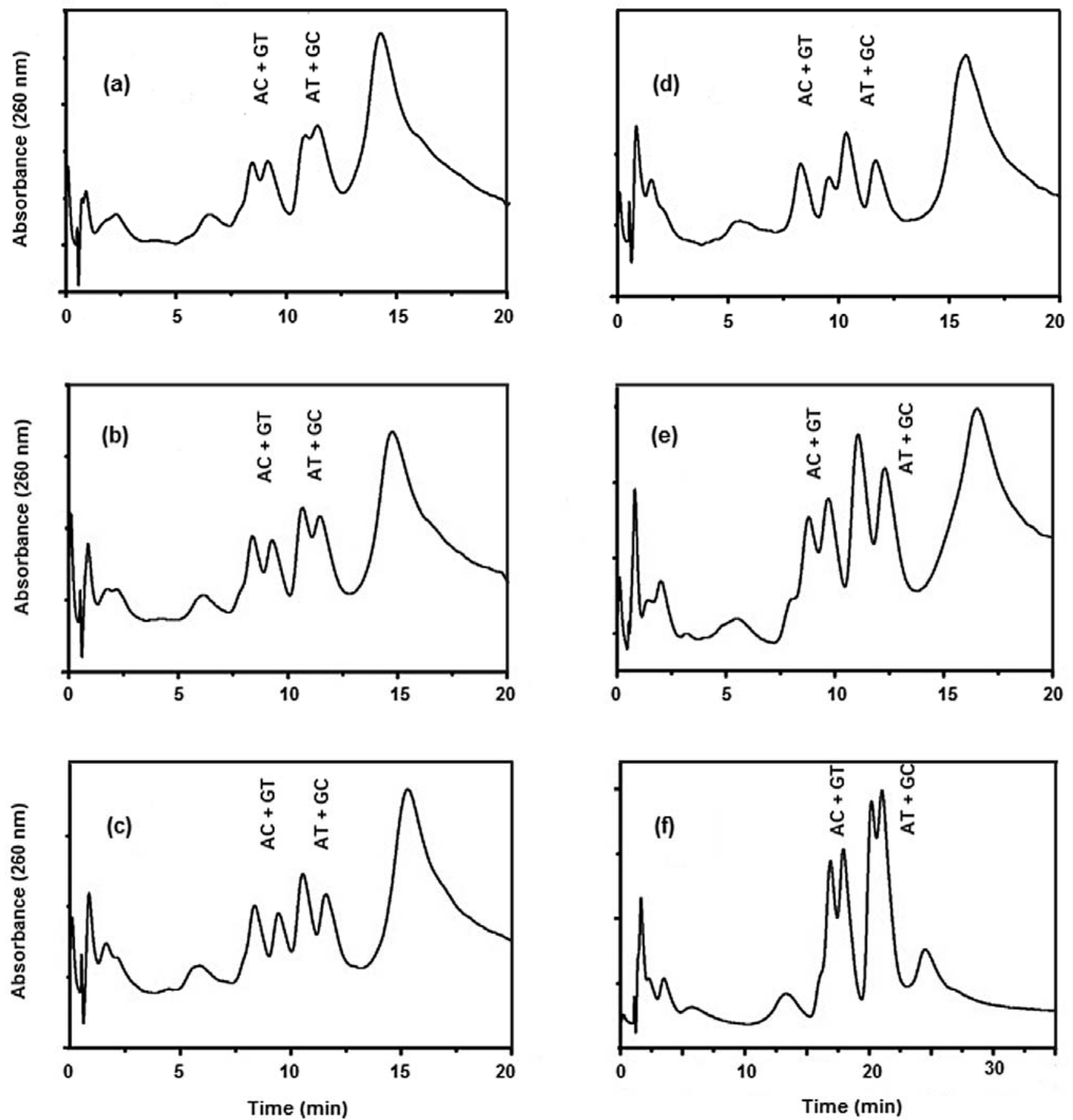

Fig. 3. Chromatograms of low-range mutation sample (209 bp)) analyzed on strong anion-exchange DVB-GMA-based monolith applying sodium phosphate buffer, showing the influence of temperature (a-d), of organic modifier (e), and of flow-rate (f). Mobile phase, A: $0.02 \mathrm{M}$ sodium phosphate buffer, $\mathrm{pH} 8.0$, (a-d, and f) $0 \%$ acetonitrile, (e) 5\% acetonitrile; B: $1.0 \mathrm{M}$ sodium chloride in A; gradient, 1-20\% B in 20 min; flow-rate, (a-e) $1.0 \mathrm{~mL} / \mathrm{min}$, (f) $0.5 \mathrm{~mL} / \mathrm{min}$; temperature, (a,f) $25^{\circ} \mathrm{C}$, (b,e) $40{ }^{\circ} \mathrm{C}$, (c) $55^{\circ} \mathrm{C}$, (d) $70{ }^{\circ} \mathrm{C}$; sample, $5 \mu \mathrm{L}$ low-range mutation sample.

\section{5. 3. Elution Order of the Mutation Sample Fragment}

Heteroduplex fragments tend to thermally denature more extensively than their corresponding perfectly matched homoduplex fragments in D-IP-RP-HPLC. Consequently, they are retained less and elute in front of the homoduplices.
Moreover the fragments rich in AT-base pairs are eluted prior to GC-base pairs. So the order of elution is AC, GT, AT, GC in D-IP-RP-HPLC. ${ }^{1,30}$ Applying AE-HPLC, the $d s$ DNA molecules begin to partially denature chemically by the electrolytic buffer present. The elution order of the heteroduplex and homoduplex fragments in the mutation sample is reversed in AE-HPLC as the latter precedes for- 


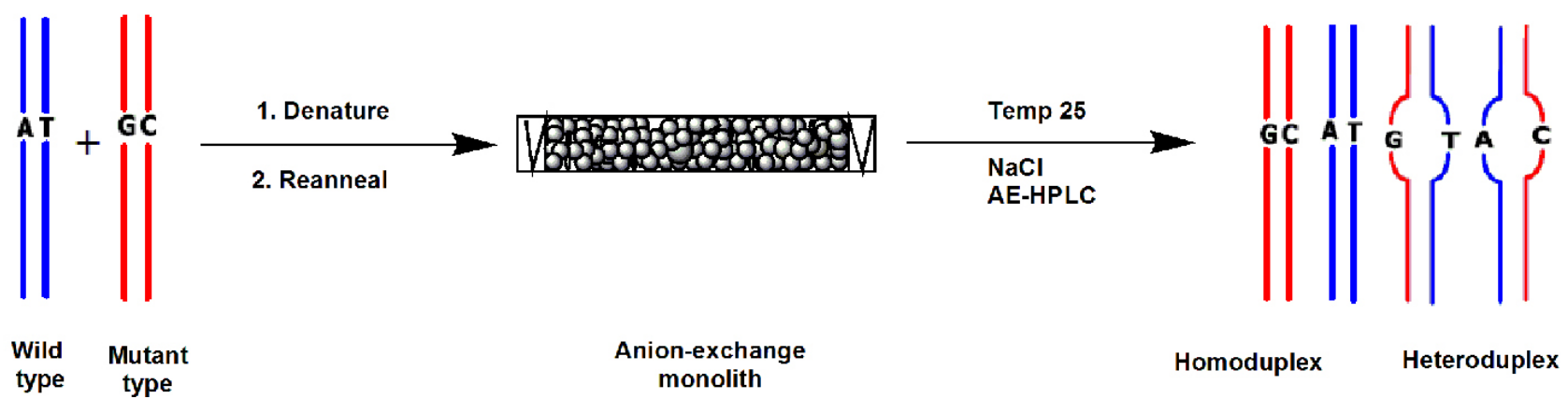

Scheme 2. Illustration of the elution order of mutation fragments of homoduplex and heteroduplex by anion-exchange high-performance liquid chromatography (AE-HPLC).

mer fragments in elution, ${ }^{16}$ where the elution mode is different in AE- from that of RP-IP-HPLC, esp. when $\mathrm{NaCl}$ is applied as a gradient former. Both size and type dependent of the DNA sequence influence the elution order, ${ }^{1-2,32}$ but since the mutation fragments are of identical size, then their elution order would be influenced by the sequence type only, so $\mathbf{G C}$ will elute before AT ${ }^{1-2,22,33}$ and the elution order would be as GC, AT, GT, then AC. (Scheme 2).

\section{6. Monolith Reproducibility, Storage and Regeneration}

The run-to-run monolith reproducibility was studied by running 15 sets of runs as four blanks followed by one sample run at the same conditions, then the column was flushed overnight by water and was conditioned the following day by mobile phase for $1 \mathrm{~h}$, and another set of analyses was done as the day before. The reproducibility of run-to-run in retention time was of relative standard deviation (RSD) of 2, 1, 2, and $1 \%$ for the AC, GT, AT, and GC, respectively). Monolith-to-monolith reproducibility was done by comparing the retention times of $\mathrm{d}(\mathrm{pT})_{12-18}$ sample for two monoliths made separately and derivatized applying the same procedure. The RSD in retention time was found to be $3,4,4,2,2,2,2 \%$ for $\mathrm{d}(\mathrm{pT})_{12-18}$ fragments, respectively.

The monolith was stored in methanol for two months, then for recheck it was washed with $200 \mathrm{ml}$ of water followed by $200 \mathrm{ml}$ of a mixture of $0.3 \mathrm{M}$ sodium acetate and $0.2 \mathrm{M}$ sodium dihydrogen phosphate to activate it. Then the monolith was flushed with mobile phase overnight. After storage the monolith did not show any decay in its efficiency, and the change in retention times of $\mathrm{d}(\mathrm{pT})_{12-18}$ fragments was less than 0.05 min.

\section{Conclusion}

Strong anion-exchange monoliths were prepared applying a new method of surface modification of glycidylmethacrylate. The monolith prepared established good separation of 5-phosphorylated oligodeoxythymidylic acids fragments $\left[\mathrm{d}(\mathrm{pT})_{12-18}\right]$, and tentative detection of mutation at room applying phosphate buffer and $\mathrm{NaCl}$ as former gradient. The four fragments of the homoduplex and heteroduplex were separated at various temperatures establishing a reliable method to detect mutation with no potential failure to spot. This makes AE-HPLC a complementary approach to D-IP-RP-HPLC method in mutation detection. Moreover, these monoliths showed high stability and reproducibility.

\section{References}

1. P. J. Oefner, C. G. Huber, J. Chromatogr. B 2002, 782, 27-55. http://dx.doi.org/10.1016/S1570-0232(02)00700-6

2. C. G. Huber, J. Chromatogr. A 1998, 806, 3-30. http://dx.doi.org/10.1016/S0021-9673(97)01124-2

3. C. G.Huber, P. J. Oefner, G. K. Bon, Chromatographia 1993, 37, 653-658. http://dx.doi.org/10.1007/BF02274118

4. J. J. Kirkland, F. A. Truszkowski, C. H. Jr. Dilks, G. S. Engel, J. Chromatogr. A 2000, 890, 3-13. http://dx.doi.org/10.1016/S0021-9673(00)00392-7

5. J. J. Meyers, A. I. Liapis, J. Chromatogr. A 1999, 852, 3-23. http://dx.doi.org/10.1016/S0021-9673(99)00443-4

6. A. I. Liapis, J. J. Meyers, O. K. Crosser, J. Chromatogr. A 1999, 865, 13-25.

http://dx.doi.org/10.1016/S0021-9673(99)01031-6

7. K. Cabrera, J. Sep. Sci. 2004, 27, 843-852. http://dx.doi.org/10.1002/jssc.200401827

8. N. Tanaka, H. Kobayashi, K. Nakanishi, H. Minakuchi, N. Ishizuka, Anal. Chem. 2001, 73, 420-429. http://dx.doi.org/10.1021/ac012495w

9. N. Tanaka, H. Kobayashi, N. Ishizuka, H. Minakuchi, K. Nakanishi, K. Hosoya, T. Ikegami, J. Chromatogr. A 2002, 965, 35-49. http://dx.doi.org/10.1016/S0021-9673(01)01582-5

10. M. R. Buchmeiser, Polymer 2007, 48, 2187-2198. http://dx.doi.org/10.1016/j.polymer.2007.02.045

11. F. Svec, C. G. Huber, Anal. Chem. 2006, 78, 2100-2108. http://dx.doi.org/10.1021/ac069383v

12. F. Svec, J. Sep. Sci. 2004, 27, 1419-1430. http://dx.doi.org/10.1002/jssc.200401825 
13. F. Svec, J. Chromatogr. B 2006, 841, 52-64. http://dx.doi.org/10.1016/j.jchromb.2006.03.055

14. H. Oberacher, C. G. Huber, P. J. Oefner, Human Mutation 2003, 21, 86-95. http://dx.doi.org/10.1002/humu.10155

15. C. G. Huber, G. N. Berti, Anal. Chem. 1996, 68, 2959-2965. http://dx.doi.org/10.1021/ac960037v

16. P. Taylor, 2002, US Pat. 164589 A1.

17. W. Haupt, A. Pingoud, J. Chromatogr. 1983, 260, 419-427.

18. S. H. Lubbad, M. R. Buchmeiser, J. Chromatogr. A 2011, 1218, 2362-2367. http://dx.doi.org/10.1016/j.chroma.2010.08.053

19. S.H. Lubbad, R. Bandari, M. R. Buchmeiser, J. Chromatogr. A 2011, 1218, 8897-8902. http://dx.doi.org/10.1016/j.chroma.2011.03.003

20. A. Strancar, A. Podgornik, M. Barut, R. Necina, $A d v$. Biochem. Eng./biotecnol. 2002, 76, 49-85.

21. E. Müller, Chem. Eng. Technol. 2005, 28, 1295-1305. http://dx.doi.org/10.1002/ceat.200500161

22 W. Bloch, 1999, US Pat. 5856192.

23.W. Wieder, C. P. Bisjak, C. W. Huck, R. Bakry, G. K. Bonn, J. Sep. Sci. 2006, 29, 2478-2484.

http://dx.doi.org/10.1002/jssc.200600146

24 V. Frankovic, A. Podgornik, N. Lendero, F. Smrekar, P.
Krajnc, A. Strancar, J. Chromatogr. A 2008, 1207, 84-93. http://dx.doi.org/10.1016/j.chroma.2008.08.027

25. Y. Wen, Y. Wang, Y. Q. Feng, Anal.Bioanal. Chem. 2007, 388, 1779-1787. http://dx.doi.org/10.1007/s00216-007-1395-8

26. N. Lendero, J. Vidic, P. Brne, V. Frankovic, A. Strancar, A. Podgornik, J. Chromatogr. A 2008, 1185, 59-70. http://dx.doi.org/10.1016/j.chroma.2008.01.023

27. C. P. Bisjak, R. Bakry, C. W. Huck, G. K. Bonn, Chromatographia 2005, 62, S31-S36. http://dx.doi.org/10.1365/s10337-005-0607-7

28. D. Bentrop, H. Engelhardt, J. Chromatogr. 1991, 556, 363-372.

29. M. Bencina, A. Podgornik, A. Strancar, J. Sep. Sci. 2004, 27, 801-810. http://dx.doi.org/10.1002/jssc.200401784

30. T. A. Sivakumaran, K. Kucheria, P. J. Oefner, Current Science 2003, 84, 291-296.

31. R. R. Iyer, A. Pluciennik, V. Burdett, P. L. Modrich, Chem. Rev. 2006, 106, 302-323. http://dx.doi.org/10.1021/cr0404794

32. H. Yamakawa, K. I. Higashino, O. Ohara, Anal. Biochem. 1996, 240, 2422-2450. http://dx.doi.org/10.1006/abio.1996.0354

33. W. Bloch, Eur. Pat. 0507591 A2.

\section{Povzetek}

Znotraj predhodno silaniziranih borosilikatnih steklenih kolon $(100 \times 3 \mathrm{~mm}$ I.D.) smo pripravili monolite poli(glicidilmetakrilat-co-divinilbenzen)-a. Te monolite smo na površini modificirali v močne anionske izmenjevalce najprej s klorovodikovo kislino (10\%) in nato s trietilaminom. Z močnim anionskim izmenjevalcem smo dosegli dobro ločbo fragmentov 5-fosforiliranih oligodeoksitimidilnih kislin $\left[\mathrm{d}(\mathrm{pT})_{12-18}\right]$. Poleg tega smo lahko pri sobni in pri povišani temperaturi ločili heterodupleks in homodupleks fragmente standarda za nizko mutacijo [STS marker pri Y-kromosomu (209 bp)], pri čemer smo za anionsko izmenjalno visokoločljivostno tekočinsko kromatografijo (AE-HPLC) uporabili pufer natrijev fosfat in natrijev klorid za nastanek gradienta. To je korak naprej proti detekciji mutacij s temperaturno neodvisno metodo, kar sicer ni slučaj pri denaturirani ionsko-parni kromatografiji na reverzni fazi (D-IP-RP-HPLC), pri kateri je detekcija mutacij kritično odvisna od temperature in jih je možno spregledati, če se temperatura nekoliko spremeni. Končni preizkus obnovljivosti od analize do analize ("run-to-run") in od monolita do monolita je pokazal relativni standardni odklon (RSD) manj kot $2 \%$. 